\title{
Biological and transcriptomic studies reveal $h f q$ is required for swimming, biofilm formation and stress response in Xanthomonas axonpodis pv. citri
}

\author{
Xuelu Liu ${ }^{1 \dagger}$, Yuping Yan ${ }^{1,2+}$, Haodi Wu' , Changyong Zhou ${ }^{1}$ and Xuefeng Wang ${ }^{1 *}$ (D)
}

\begin{abstract}
Background: $\mathrm{Hfq}$ is a widely conserved bacterial RNA-binding protein which generally mediates the global regulatory activities involv ed in physiological process and virulence. The goal of this study was to characterize the biological function of $h f a$ gene in Xanthomonas axonpodis pv. citri (Xac), the causal agent of citrus canker disease.

Results: An hfq mutant in Xac was generated by plasmid integration. The loss of hfq resulted in attenuation of bacterial growth, motility and biofilm formation. In addition, the $h f q$ mutation impaired Xac resistance to $\mathrm{H}_{2} \mathrm{O}_{2}$ and both high and low pH environments, but did not affect the virulence to citrus. RNA-Seq analyses indicated that Hfa played roles in regulating the expression of 746 genes. In hfa mutant, gene expression related to chemotaxis, secretion system, two-component system, quorum sensing and flagellar assembly were repressed, whereas expression of ribosomal genes were significantly up-regulated. The down-regulated expression of three bacterial chemotaxis related genes and seven flagella genes, which involved in cell growth and biofilm formation, were further validated by RT-qPCR.
\end{abstract}

Conclusions: The study demonstrated that $h f q$ was involved in multiple biological processes in Xac. The results could serve as initiate points for identifying regulatory sRNAs and genes controlled by Hfq-sRNA interactions in Xac.

Keywords: Xanthomonas axonpodis pv. citri, Xanthomonas citri subsp. citri, hfa gene, Biofilm

\section{Background}

The RNA chaperone Hfq was originally discovered in Escherichia coli as a host factor essential for replication of the bacteriophage $\mathrm{Q} \beta[1,2]$ and afterwards identified in a large number of Gram-positive and Gram-negative bacterial species [3]. Hfq forms a hexameric ringshaped doughnut structure that mediates the global post-transcriptional regulation involved in numerous physiological and biochemical functions in bacteria [2]. Inactivation of $h f q$ gene exhibits broadly pleiotropic phenotypes in Escherichia coli, e.g. alteration in growth rate and tolerance to UV or high

\footnotetext{
* Correspondence: wangxuefeng@cric.cn

${ }^{+}$Xuelu Liu and Yuping Yan contributed equally to this work.

'National Engineering Research Center for Citrus, Citrus Research Institute, Southwest University/Chinese Academy of Agricultural Sciences, Chongqing 400712, People's Republic of China

Full list of author information is available at the end of the article
}

osmolarity stresses [4]. Many $h f q$ mutants from a broad spectrum of bacterial pathogens show a general role in bacterial physiology and virulence [3, 5-7]. Notably, $h f q$ deficiency impairs the stability and functional activation of many Hfq-dependent small non-coding RNAs (sRNAs) which are usually encoded in the intergenic regions of bacterial genomes [8]. The majority of these Hfq-dependent sRNAs can modulate the expression of target mRNAs by base pairing mechanisms, and then affect the downwards cellular processes $[9,10]$. Thus, Hfq protein in facilitating the interaction between small non-coding RNAs (sRNAs) and target mRNAs is currently considered as its most prominent function.

Xanthomonas spp. are economically important phytopathogens and are grouped into pathovars (pv.) based on their specific host ranges $[11,12] . X$. oryzae pv. oryzae 
(Xoo), X. campestris pv. vesicatoria $(X c v), X$. campestris pv. campestris $(X c c)$ and $X$. axonpodis pv. citri (Xac) (synonym $X$. citri subsp. citri) are economical important pathogens among the genus Xanthomonas. hfq is conserved in Xanthomonas spp. and has been investigated in Xoo and Xcv. Inactivation of $h f q$ in Xoo affects it growth in complex medium, but does not disrupt its virulence [13]. Similarly, $h f q$ gene in $X c v$ does not involve in virulence [14]. Although many Hfq-dependent sRNAs were identified in $X c v, X c c$, and Xoo [15-17], their involvements in regulation and virulence function have been poorly characterized. Xanthomonas axonpodis pv. citri $(X a c)$, the causal agent of citrus canker, is an important bacterial pathogen that severely affects citrus production worldwide. The two key regulators, HrpG and HrpX, regulating type III secretion system (T3SS), are known to play a critical role in Xac infection [16]. However, the roles of global regulator $h f q$ and its related sRNAs remain to be determined.

In this study, the function of $h f q$ in Xac biology and gene expression was characterized by using an $h f q \mathrm{mu}-$ tant constructed in strain Xac29-1. The inactivation of $h f q$ resulted in the phenotypic alterations in bacterial growth, swimming motility, biofilm formation and stress response. Results of RNA-Seq analyses indicated that Hfq plays an important role in multiple biological processes including chemotaxis, flagellar assembly and secretion systems.

\section{Results}

\section{The deletion of $h f q$ attenuates the Xac growth and} swimming

A mutant named $X a c \Delta h f q$ was generated by plasmid integration and confirmed by PCR and Southern blot (Additional file 1: Figure S1). Wild type Xac29-1, mutant $X a c \Delta h f q$ and its complemented strain Xac $\Delta h f q-C$ were cultured in NB media to examine their growth curve. As shown in Fig. 1, the loss of $h f q$ led to remarkably reduced growth rate, while was restored by the complemented strain. The growth rate of $h f q$ mutant was very close to wild type at stationary growth stage (36 h).

The cell motility ability was evaluated on $0.3 \%(\mathrm{w} / \mathrm{v})$ NA plates. The diameters of the motility zone derived from $h f q$ mutant reduced by almost $60 \%$ when compared with the wild type. The complemented mutant strain $X a c \Delta h f q-\mathrm{C}$ restored the motility (Fig. 2).

\section{hfq gene was involved in Xac biofilm formation, but did not affect $X a c$ virulence}

To assess biofilm formation, the strains were grown statically in borosilicate glass tubes in NB medium for 3 days. Staining of bacterial cells with crystal violet $(\mathrm{CV})$ stain showed that Xac29-1 and Xac $\Delta h f q-C$ produced much more biofilms of cell mass adhered to the glass surface than those produced by Xac $\Delta h f q$ strain. Accordingly, the absorbance value of crystal violet from wild type was over three times greater than that of the $h f q$ mutant (Fig. 3). A cell-counting kit (CCK)-8 assay was conducted to evaulate the cell viability, and the results demonstrated that cell viability was only slightly inhibited in $h f q$ mutant and no significant difference was found between Xac29-1 and $h f q$ mutant (Data not shown).

For pathogenicity test, wound infection assay in sweet orange leaves was used. At 4 days post inoculation, all strains induced spongy-like canker symptoms, indicating that $h f q$ does not contribute to the virulence of Xac (Additional file 2: Figure S2).

\section{The $h f q$ mutation impairs bacterial resistance to hydrogen peroxide $\left(\mathrm{H}_{2} \mathrm{O}_{2}\right)$ and $\mathrm{pH}$}

Compared with the NB medium, the growth of the $h f q$ mutant almost showed no difference at the low concentration $(0.001 \mathrm{mM})$ of $\mathrm{H}_{2} \mathrm{O}_{2}$, whereas the growth of the mutant was inhibited at $0.01 \mathrm{mM} \mathrm{H}_{2} \mathrm{O}_{2}$. The resistance of $\mathrm{Xac}$ to high and low $\mathrm{pH}$ was significantly affected by the mutation of $h f q$ although the growth of complementation strain was also slightly affected at the high and low $\mathrm{pH}$ conditions (Fig. 4, Additional file 3: Figure S3). Taken together, the $h f q$ mutation impairs Xac resistance to $\mathrm{H}_{2} \mathrm{O}_{2}$ and $\mathrm{pH}$.

\section{Global RNA expression changes in $h f q$ mutant of $X a c$}

RNA-Seq data have been submitted to the NCBI database and the accession numbers of wild type and $h f q$ mutant are PRJNA477585 and PRJNA477663, respectively. Disruption of $h f q$ significantly changed expression of 746 genes. Of them, 662 genes were down-regulated and 84 genes were up-regulated. The differential expressed genes (DEGs) were enriched into different function categories through Gene ontology (GO) enrichment analysis (Additional file 3: Figure S3). The most significant GO terms in cellular component GO terms included cellular component (GO:0005575), membrane (GO:0016020), membrane part (GO:0044425) and intrinsic to membrane (GO:0031224). Besides, localization (GO:0051179) and transport (GO:0006810) in biological process GO term, receptor activity (GO:0004872) in molecular function GO term were also enriched (Additional file 4: Figure S4). Kyoto Encyclopedia of Genes and Genomes (KEGG) pathway enrichment analysis showed that most of DEGs in pathways related to bacterial chemotaxis, bacterial secretion system, two-component system, quorum sensing and flagellar assembly were repressed, while the ribosome related genes were significantly up-regulated in $h f q$ mutant (Additional file 5: Table S1). 


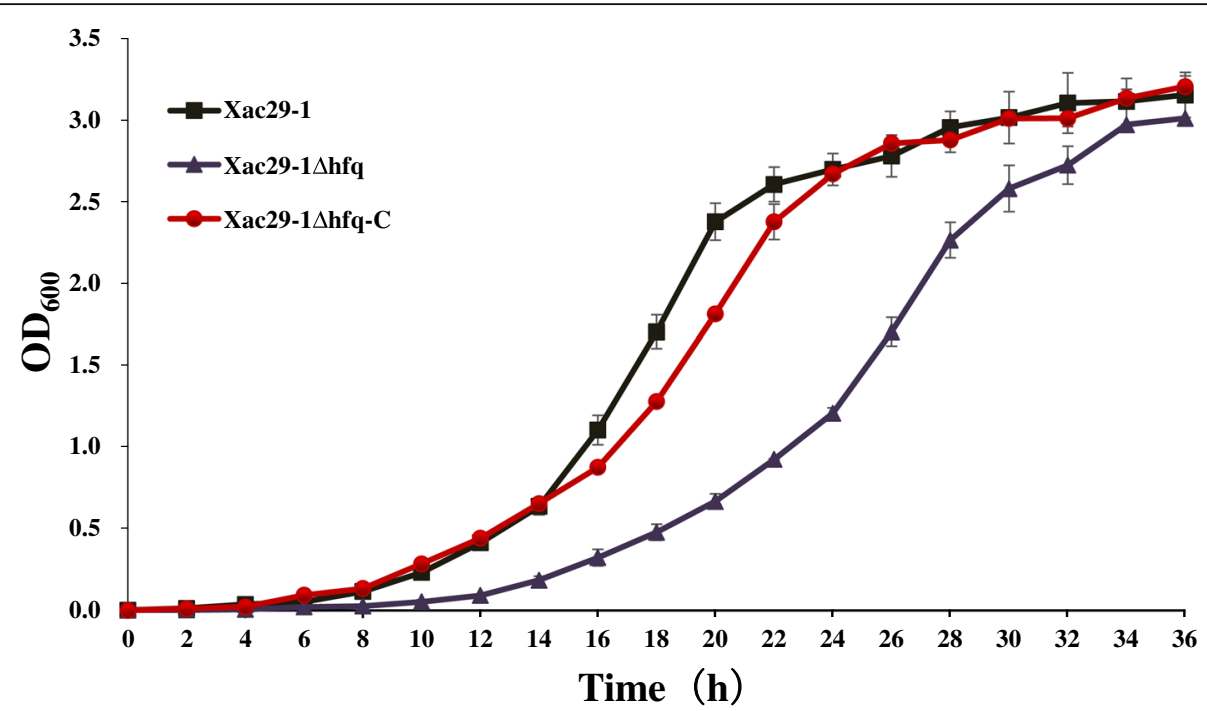

Fig. 1 The growth curve of Xac29-1, Xac29-1 $\Delta h f q$ and Xac29-1 $\Delta h f q-C$ in NB culture medium for $36 \mathrm{~h}$. The experiment was repeated three times

To validate the RNA-seq data, 26 genes related with chemotaxis, flagella biosynthesis, secretion system and ribosome were chosen for RT-qPCR (Fig. 5). The expression trends of 24 genes were similar with those revealed by RNA-seq results, demonstrating the reliability of RNA-seq analysis. The down-regulation expression of XAC29_11660 (50S ribosomal protein L36) and XAC29_17265 (50S ribosomal protein L31) by RT-qPCR was inconsistent with those obtained from the RNA-seq.

\section{Discussion}

Although the inactivation of $h f q$ in different bacterial species has exhibited a pleiotropic phenotype [4, 17-19], its deletion in the genus Xanthomonas displayed similar alterations in growth and motility $[13,14]$. In this study, the mutation in $h f q$ gene resulted in remarkably reduced bacterial growth rate. Additionally, the deletion of $h f q$ led to a reduction of cell swimming ability by $60 \%$ and biofilm formation was reduced by almost $70 \%$. Transcriptome and RT-qPCR analysis showed that three bacterial chemotaxis related genes, cheR, che $A$, cheW, and seven flagella genes, fliD, fliR, flhA, flhB, $\operatorname{chp} A$, motA, $\operatorname{mot} B$, were significantly repressed in the $h f q$ mutant (Additional file 5: Table S1). CheA, CheW and CheR are core proteins of chemosensory pathways which are essential for motility and pathogenicity in many bacteria [20]. Transcriptome data related to chemotaxis and flagellar assembly strongly supported the biological results of the attenuation of cell motility and biofilm formation (Fig. 5, Additional file 5: Table S1).

Hfq is a common regulator of virulence in bacteria [3]. However, the virulence-related defects are not common in plant-pathogenic bacteria and only reported in a few bacteria, i.e., Agrobacterium tumefaciens and Erwinia
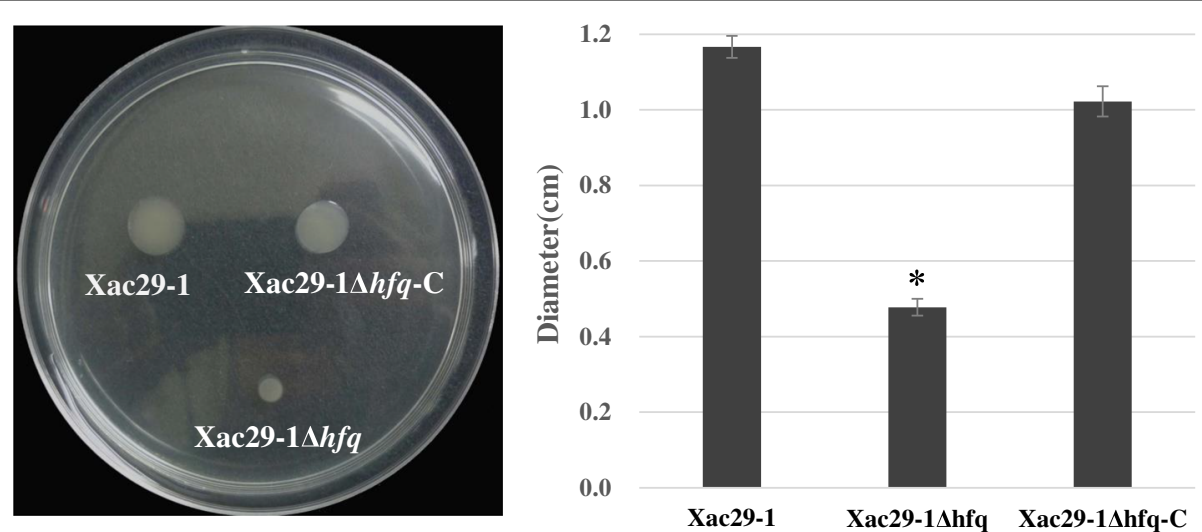

Fig. 2 Swimming pattern of Xac29-1, Xac29-1 $\Delta h f q$ and Xac29-1 $\Delta h f q-C$ in NB medium at 48 h post inoculation. The swimming motility was measured from the diameter of each colony. The experiment was repeated three times. The asterisks in horizontal data column indicate significant differences at $P=0.01$ by $t$ test 


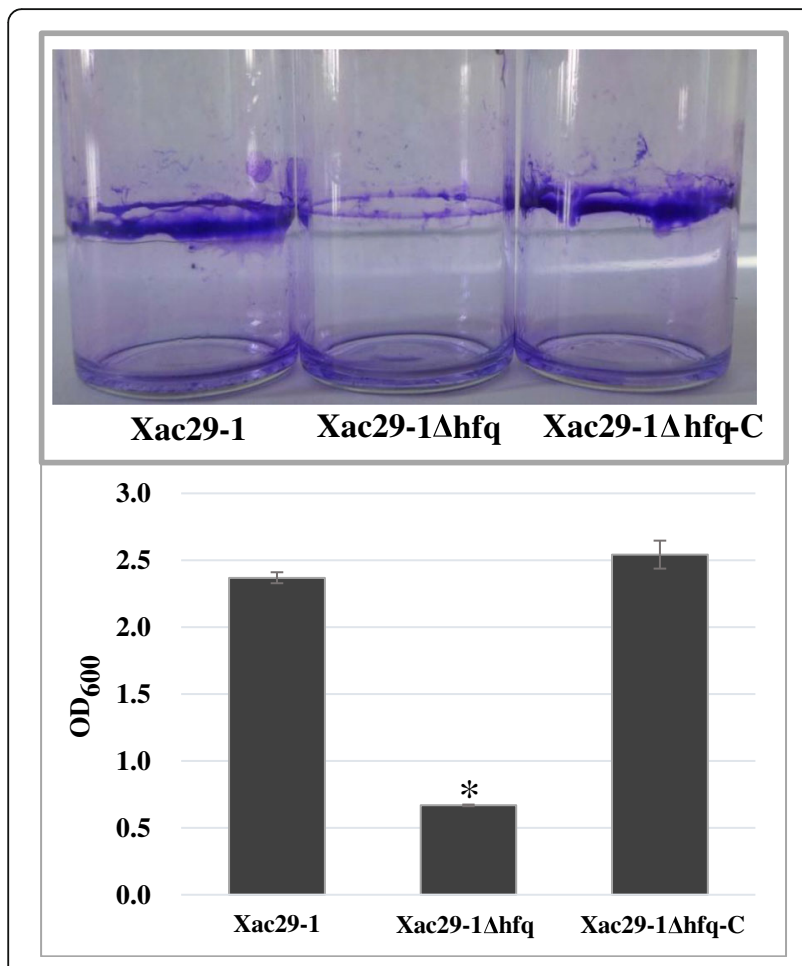

Fig. 3 Biofilm formation of Xac29-1, Xac29-1 $\Delta h f q$ and Xac29-1 $\Delta h f q-C$ on glass bottle surfaces after 3 days incubation. The results of the biofilm formation assays were quantified by measuring the absorbance of the crystal violet stain at $600 \mathrm{~nm}$. The tests were repeated three times. The asterisks in horizontal data column indicate significant differences at $P=0.01$ by $t$ test

spp. $[5,21]$. Hfq significantly regulated type III secretion system and the other related pathogenicity determinants in E.amylovora [5]. hfq mutant attenuates the tumor formation and influences the virulence of A. tumefaciens, but the DNA-transferring type IV secretion system is not affected [21]. Transcriptome analysis showed that $h f q$ significantly regulated chemotaxis, bacterial secretion systems, two-component system, quorum sensing and flagellar assembly in Xac. Regarding the expression profile of the genes associated with secretion systems (type I to type VI), those from type IV and type V secretion systems were unaltered, whereas two genes in type I were slighted repressed and 18 genes from type II, III, VI secretion systems were significantly decreased (over 2 folds) in $h f q$ mutant (Additional file 5: Table S1). Similar with previous studies on $X o o$ and $X c v(13,14)$, the virulence of the $h f q$ mutant of Xac also did not affected through wound infection assay. It should be noted that virulence phenotype between $\mathrm{Xac}$ wild type and waxcO mutant had no difference by wound infiltration, whereas significant differences in lesion numbers were observed by spray assay [22]. Non-wound inoculation, spraying or swabbing, remains to be used to check the pathogenicity phenotype of $h f q$ mutant of Xac, Xoo and Xcv.
It is interesting that nine ribosomal protein genes were significantly up-regulated through transcriptome data. Of the nine proteins, RpsE codes for $30 \mathrm{~S}$ subunit ribosomal protein S5 and the other eight proteins are components of the ribosomal large subunit. It should be note that there was about four-fold expression increase for rplU-rpmA, encodes for $50 \mathrm{~S}$ subunit r-proteins L21 and L27, respectively (Additional file 5: Table S1). RT-qPCR also proved the high expression of the operon genes in hfq mutant (Fig. 5). L27, consisting of a C-terminal $\beta$-sandwich domain and a long $\mathrm{N}$-terminal arm, plays a key role in tRNA substrate stabilization during the peptidyl transfer reaction [23, 24]. RpsE has been implicated in tRNA selection and translation fidelity in E. coli [25]. Although it remains unclear how Hfq affects these ribosomal proteins of $\mathrm{Xac}$, the expression differences of ribosomal proteins, probably resulted in reduced translation accuracy, might also play certain roles in the pleiotropic defects of $h f q$ mutants.

Many sRNA candidates in genus Xanthomonas have been generated by high-throughput transcriptome sequencing approaches [13-15]. Of these sRNAs, 44 sRNAs were so far experimentally verified in $\mathrm{Xoo}, \mathrm{Xcv}$ and Xcc [26]. It should be noted that the accumulation and activity of only six sRNAs were closely related with $h f q$ whereas some sRNAs involved in virulence, i.e. sX12 and sX13, were assumed to act Hfq-independent (14, 26). It might partially explain why the $h f q$ mutant strain of Xanthomonas spp. was not altered in the induction of virulence phenotype. So far, the function of $\mathrm{Hfq}$ is still obscure in Xanthomonas spp. and its physiological roles and RNA-binding capability is needed to be further addressed. This study is a good starting point for identifying regulatory sRNAs and genes controlled by Hfq-sRNA interactions in Xac.

\section{Conclusions}

In this study, biological analyses of the $h f q$ mutant clearly point toward the requirement for $\mathrm{Hfq}$ function in multiple biological processes in $X a c$, i.e. motility, biofilm formation and stress response. RNA-seq data showed that 746 genes were regulated by $h f q$ gene, reflecting its global regulation role in Xac. In particular, the expression of genes associated with bacterial chemotaxis and flagellar assembly were significantly down-regulated in the $h f q$ mutant, consistent with the reduction of swimming and biofilm formation.

\section{Methods}

Bacterial strains, plasmids and growth conditions

The bacterial strains and plasmids used in this work are listed in Table 1. Xanthomonas strains were grown at $28^{\circ} \mathrm{C}$ in nutrient broth (NB) medium or on NA (NB with 1.5\% Agar). Escherichia coli strains were cultured at $37^{\circ} \mathrm{C}$ in 


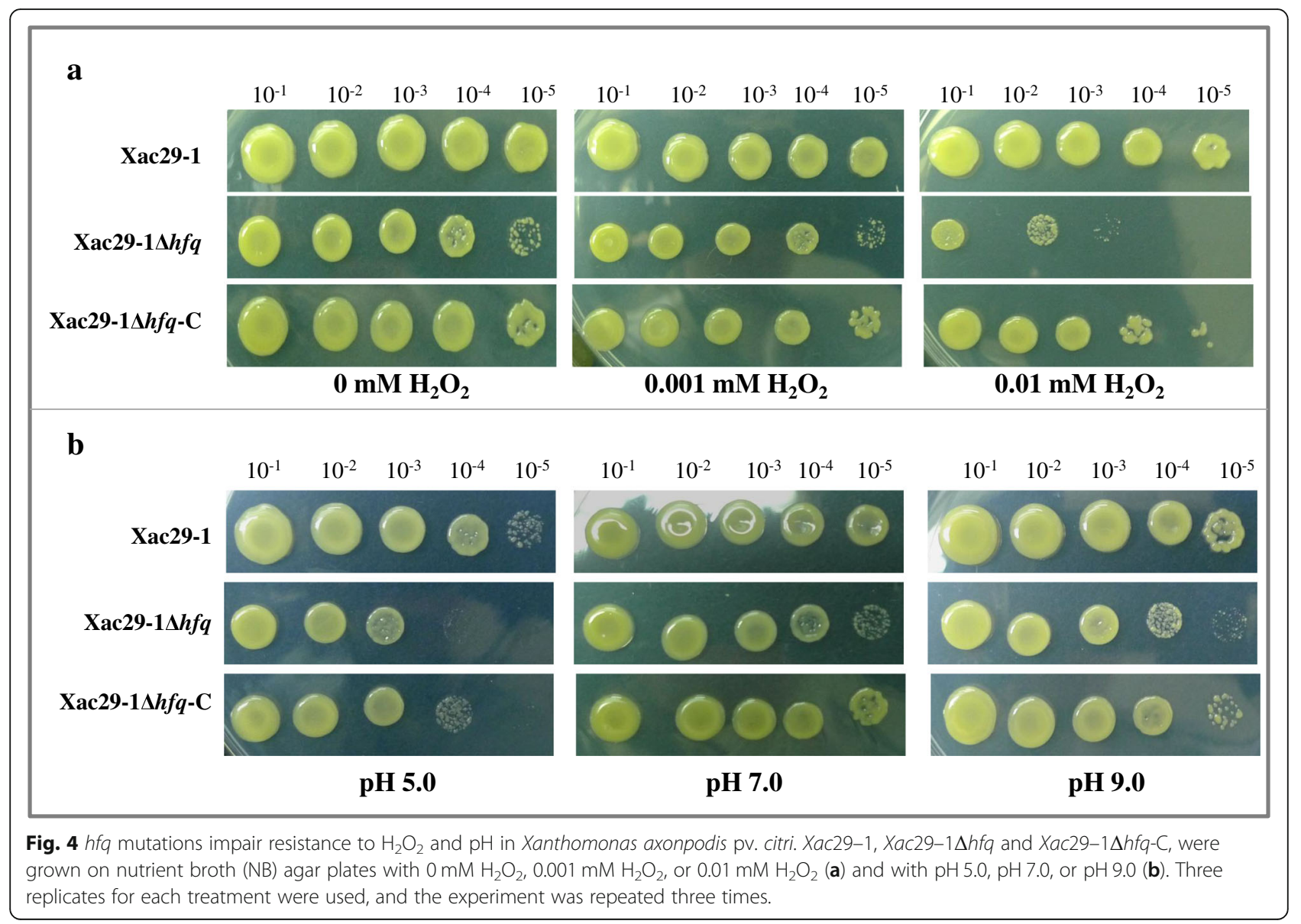

Luria-Bertani (LB) medium or on LA (LB with 1.5\% Agar). When required, the antibiotics kanamycin $(50 \mu \mathrm{g} / \mathrm{ml})$ and gentamycin $(10 \mu \mathrm{g} / \mathrm{mL})$ were added to the growth media.

\section{Construction of the $h f q$ deletion mutant and its complemented strain}

The $h f q$ mutant was generated from Xac29-1 wild type strain by allelic homologous recombination. Briefly, two $h f q$ flanking regions were amplified by $\mathrm{PCR}$ using the primer pairs up F/R and down F/R (Table 1). The PCR products of upstream and downstream were digested with $B a m \mathrm{HI} / K p n \mathrm{I}$ and $K p n \mathrm{I} / X b a \mathrm{I}$, respectively. The digested fragments were ligated into the suicide vector $\mathrm{pK} 18 \mathrm{mobSacB}$ to obtain the recombinant plasmid pK18mobSacB- $\Delta h f q$. The plasmid was transformed into wild type strain Xac29-1 by electroporation. The $h f q$ mutant, named Xac29-1 $h h f q$, was obtained after two recombination events and confirmed by PCR and Southern blotting.

To complement the $h f q$ mutant, DNA fragment containing the entire $h f q$ gene and its upstream promoter was amplified. The amplified fragment was digested with HindIII/EcoRI enzyme and cloned into HindIII/EcoRI-digested pBBR1MCS-5 [27], resulting in pBBR1MCS-5 + hfq plasmid. The complementary plasmid was transformed and one complemented mutant strain, named Xac29-1 $h h f q-C$, was selected on NA plate with Gentamycin resistance.

\section{Determination of growth curve}

Pellets of Xac29-1, Xac29-1 $h$ hfq and Xac29-1 $\Delta h f q-C$ strains were cultured in NB medium and adjusted to an $\mathrm{OD}_{600}=0.6$ and then sub-cultured (1100) in fresh NB for $36 \mathrm{~h}$. The $\mathrm{OD}_{600}$ values were tested after every $2 \mathrm{~h}$ post sub-culturing. All the experiments were repeated at least three times.

\section{Motility assay}

To test cell motility, all strains were grown overnight in $\mathrm{NB}$ medium and adjusted to an $\mathrm{OD}_{600}=0.6\left[10^{8}\right.$ colony-forming units $(\mathrm{cfu}) / \mathrm{mL}$ ]. $2 \mu \mathrm{L}$ of each cell sample was dropped to $0.3 \%$ agar NA plates for the swimming motility tests [18]. The diameters of each colony were measured after $48 \mathrm{~h}$ of incubation, and the resulting values were taken to indicate the bacterial motility. 


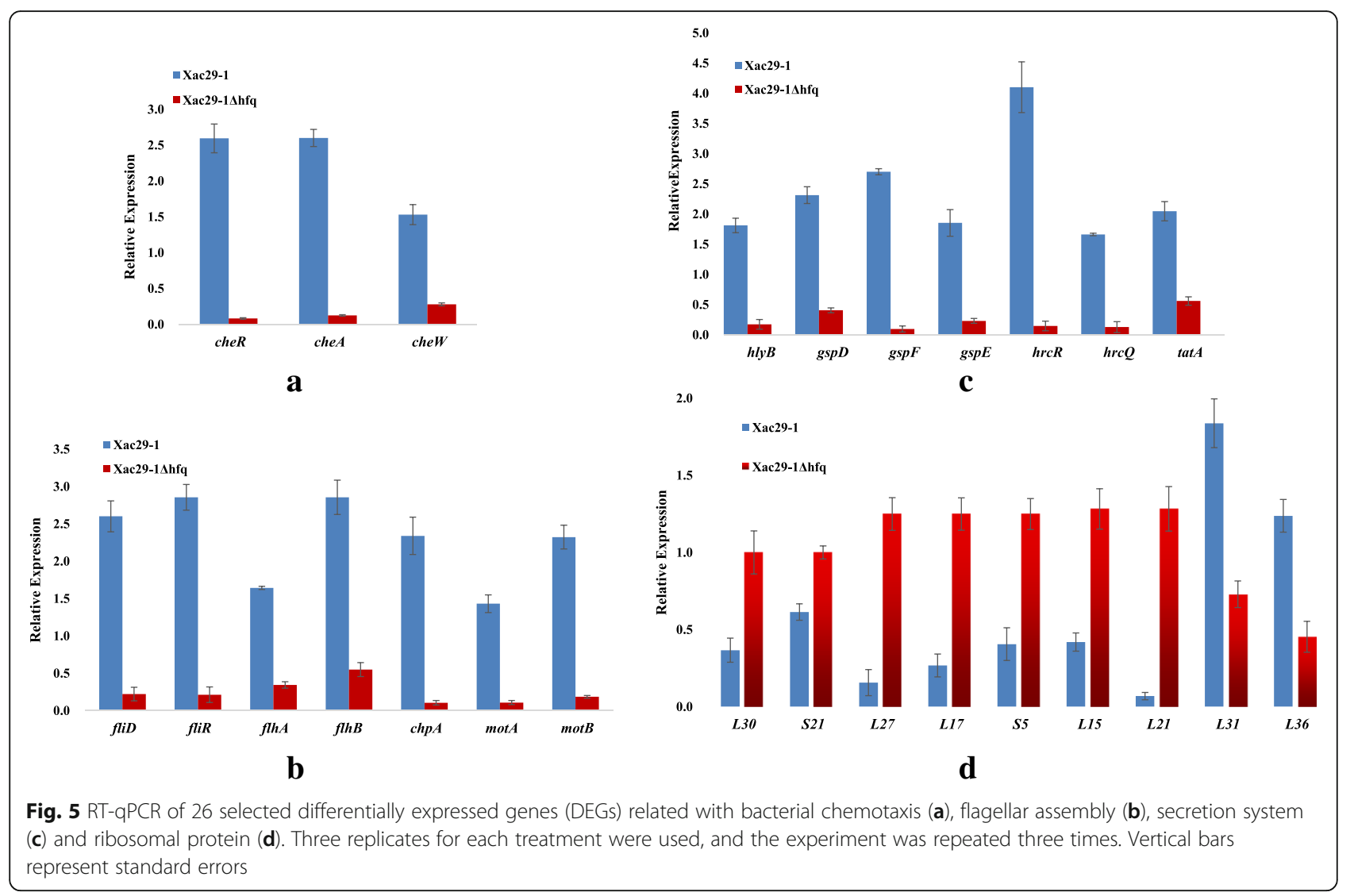

Table 1 Strains, plasmids and primers used in this study

\begin{tabular}{|c|c|c|}
\hline Strains, plasmids and primers & Feature & Source \\
\hline \multicolumn{3}{|l|}{ Strains } \\
\hline Xac29-1 & $\mathrm{G}^{-}, \mathrm{wt}$ & Ye et al. (2013) \\
\hline Xac29-1 $14 f q$ & $\mathrm{G}^{-}, \Delta h f q$ & This study \\
\hline Хac 9-1 $\Delta h f q-C$ & $\mathrm{G}^{-}, h f q^{+}$ & This study \\
\hline JM109 & $\mathrm{G}^{-}$ & Takara \\
\hline \multicolumn{3}{|l|}{ Plasmids } \\
\hline pEASY-T1 & $\mathrm{Kan}^{+} / \mathrm{Amp}^{+}$ & TransGen \\
\hline pK18mobSacB & $\mathrm{Kan}^{+}, \mathrm{SacB}$ & Zou et al. (2011) \\
\hline pK18mobSacB- $\Delta h f a$ & $\mathrm{Kan}^{+}, \mathrm{SacB}, h \mathrm{hq}^{+}$ & This study \\
\hline pBBR1MCS-5 & $\mathrm{Gm}^{+}$ & Zou et al. (2011) \\
\hline \multicolumn{3}{|l|}{ Primers } \\
\hline$h f q-\mathrm{F}$ & 5'-GCTTCAGGCGTGTAACATCC-3' & This study \\
\hline$h f q-R$ & 5'-GCGAACTCCTCCAACACATC-3' & This study \\
\hline hfq-up-F & 5'-TGGGATCCCGCGTGTTGAAGGTGGTATT-3' & This study \\
\hline hfq-up-R & 5'-TGGGTACCCGAAAAATCCTCTTCATTATTGT-3' & This study \\
\hline hfa-down-F & 5'-TGGGTACCCGGAGTAGTGCGTGTTTGATC-3' & This study \\
\hline hfa-down-R & 5'-GCTCTAGAAAGCCTCTGCACCGGTCAACA-3' & This study \\
\hline$h f q-\mathrm{F} 1$ & ATGGCTAAGGGGCAATCTTTAC & This study \\
\hline$h f q-R 1$ & ACCGATCAAACACGCACTACT & This study \\
\hline
\end{tabular}




\section{Biofilm formation assay}

Biofilms that formed on polystyrene and glass surfaces were examined as previously described [28]. Briefly, $5 \mu \mathrm{L}$ of each adjusted cell sample was transferred to a glass bottle containing $5 \mathrm{~mL}$ fresh $\mathrm{NB}$ medium and stationary incubated at $28{ }^{\circ} \mathrm{C}$ for 3 days. After the medium removal and washing, bacteria were stained with $5 \mathrm{~mL}$ crystal violet for $5 \mathrm{~min}$. Excess crystal violet stain was removed to observe a circle of purple material formed on the glass bottle. The crystal violet dye was solubilized by addition of $5 \mathrm{~mL}$ organic solvent (anhydrous ethanol: acetone $=70: 30, \mathrm{v} / \mathrm{v}$ ), then crystal violet was quantified by measuring absorbance at $600 \mathrm{~nm}$. All the experiments were repeated three times and the average for each strain was checked by $t$-test.

\section{Cell viability assay}

A CCK-8 assay was used to determine the cell viability of Xac29-1, Xac29-1 $\Delta h f q$ and Xac29-1 $\Delta h f q-C$ strains incubated at $28{ }^{\circ} \mathrm{C}$ for 3 days. $100 \mu \mathrm{L}$ of each cell sample and $10 \mu \mathrm{L}$ CCK-8 (BioDee Biotechnology, Beijing, China) were plated into 96-well plates and incubated at $37^{\circ} \mathrm{C}$ for $4 \mathrm{~h}$. Then the absorbance was measured at $450 \mathrm{~nm}$ wavelength. Each group had three wells and all experiments were repeated three times.

\section{Stress resistance assays}

The resistance assay against $\mathrm{H}_{2} \mathrm{O}_{2}$ was performed as described previously [29] with minor modifications. Xac29-1, Xac29-1 $\Delta h f q$ and Xac29-1 $\Delta h f q-C$ strains were cultured in $\mathrm{NB}$ medium and adjusted to an $\mathrm{OD}_{600}$ $=0.6 . \mathrm{H}_{2} \mathrm{O}_{2}$ with a concentration of $0.1 \mathrm{mM}$ and 0.001 $\mathrm{mM}$, were supplemented to the bacterial suspension and incubated at $28^{\circ} \mathrm{C}$ for $10 \mathrm{~min}$ with shaking, respectively. The challenged bacterial cells were diluted by 5 gradients $\left(10^{-1}, 10^{-2}, 10^{-3}, 10^{-4}, 10^{-5}\right), 2 \mu \mathrm{L}$ of each cell sample was dropped on NA plates respectively and stationary incubated at $28^{\circ} \mathrm{C}$ for 3 days.

$\mathrm{pH}$ stress testing was similar with that of $\mathrm{H}_{2} \mathrm{O}_{2}$ testing. The adjusted bacterial population was diluted by 5 serial dilutions $\left(10^{-1}, 10^{-2}, 10^{-3}, 10^{-4}, 10^{-5}\right) .2 \mu \mathrm{L}$ of each cell sample was dropped on NA plates with $\mathrm{pH}$ of 5.0, 6.0, 7.0, 8.0, 9.0, respectively.

\section{Pathogenicity assay}

Strains were cultured and adjusted to an $\mathrm{OD}_{600}=0.6$. The full expanded leaves of pineapple sweet orange (Citrus sinensis) were used as host materials. Five wounds were produced on the back of the leaves with a needle. $10 \mu \mathrm{L}$ of each cell suspension were then placed on the wounds. Disease symptoms were observed and photographed 2 days post inoculation [30]. Each test was repeated at least three times.
RNA extraction, library preparation and RNA sequencing Bacterial cultures from wild-type and $h f q$ mutant strains were collected in the middle exponential stage $\left(\mathrm{OD}_{600}=\right.$ 0.6-0.8). RNAs were extracted using the RNA prep pure Cell/Bacteria Kit (Tiangen Biotech, Beijing, China). Strand-specific RNA-seq libraries were generated using NEBNext $^{\oplus}$ Ultra $^{\mathrm{Tm}}$ Directional RNA Library Prep Kit for Illumina $^{\circ}$ (NEB, USA). After cluster generation, the library preparations were sequenced on an Illumina Hiseq platform (Illumina, CA, USA) in Novogene, Tianjing.

\section{Transcriptome data analysis}

After cleaning the raw reads, we mapped the clean reads to the complete genome Xac29-1 strain (CP004399.1, CP004402.1, CP004401.1 and CP004400.1) using Bowtie 2 [31] and then calculated gene expression level with RSEM [32]. Differentially expression analysis was performed using the DESeq $\mathrm{R}$ package (1.18.0). The $p$-values were adjusted for the false discovery rate (FDR). Genes with an adjusted $p$-value $<0.05$ and $\mid \log _{2}$ (Fold Change) $\mid>1$ were considered to be differentially expressed genes at a statistically significant level. A $t$-test was performed on $\log _{2}-$ transformed data to identify the genes with significant changes in expression between wild type and mutant strains. Gene Ontology (GO) terms with corrected $P$ value $\leq 0.05$ were considered significantly enriched by differentially expressed genes.

\section{RT-qPCR}

To assess the RNA-seq quality, the same set RNAs for RNA-seq were subjected to a two-step RT-qPCR assay with Bio-Rad iQ5 Real Time PCR System (Bio-Rad, CA, USA) using SYBR green RT-PCR kit (Promega). 26 genes related with bacterial chemotaxis, flagellar assembly, bacterial secretion and ribosome were chosen for RT-qPCR (Additional file 6: Table S2). The 16S rRNA gene was used as an endogenous control. The relative fold change in target gene expression was calculated using the $2^{-\Delta \Delta C T}$ method [33].

\section{Additional files}

Additional file 1: Figure S1. PCR and southern blotting confirmation of the $h f q$ mutant. (A) The gene deletion scheme. The 480-bp (amplified by hfq-up-F/R) (Table 1) and 680-bp (amplified by hfq-down-F/R) (Table 1) DNA fragments were used as the 5 'and 3 'fragments for homologous recombination, respectively. The 278-bp DNA fragment of $h f a$ gene was deleted in the $h f q$ mutant. The $h f q-F / R$ primer (Table 1) was used for molecular confirmation of the hfq mutant. If the 278-bp fragment of $h f q$ gene was successfully deleted, a 195-bp DNA fragment would be amplified from the mutant. (B) PCR confirmation of the hfq mutant. M, Mark; 1-6, hfa deletion mutant; 7-8, Xac29-1 wild type strain; 9, pK18mobSacB- $\Delta h f$, positive control; $10, \mathrm{H}_{2} \mathrm{O}$, negative control. (C) Southern blotting analysis of the $h f a$ deletion mutant. The 794-bp fragment was used as the probe for Southern blotting. A 1.8-kb DNA fragment was detected in the Xac29-1 
wild-type strain (lane 3), whereas only an approximately1.5-kb fragment was obtained in the $h$ fa deletion mutant (lane 1 and 2) owing to the deletion of the 279-bp fragment. (PPTX $61 \mathrm{~kb}$ )

Additional file 2: Figure S2. The pathogenicity test of Xac29-1 strain, hfq mutant and complementary strain by wound infection on detached citrus leaves. Each test was repeated at least three times. (PPTX $116 \mathrm{~kb}$ )

Additional file 3: Figure S3. $\mathrm{hfq}$ mutations impair resistance to $\mathrm{pH}$ in Xanthomonas axonpodis pv. citri (repeat experiment). Xac29-1, Xac29$1 \Delta h f q$ and $X a c 29-1 \Delta h f a-C$, were grown on nutrient broth (NB) agar plates with pH 5.0, pH 7.0, or pH 9.0. (PPTX $801 \mathrm{~kb}$ )

Additional file 4: Figure S4. Gene ontology (GO) enrichment analysis of differentially expressed genes (DEGs) of Xac29-1 wild-type strain compared with hfo mutant. Up, up-regulation; Down, own-regulation. (PPTX $63 \mathrm{~kb}$ )

Additional file 5: Table S1. List of the differentially expressed genes in bacterial chemotaxis, two-component system, secretion system, quorum sensing, flagellar assembly and ribosome. (DOCX $20 \mathrm{~kb}$ )

Additional file 6: Table S2. The primers used for RT-qPCR validation. (DOCX $17 \mathrm{~kb})$

\section{Abbreviations}

CV: Crystal violet; DEG: Differentially expressed gene; FDR: False discovery rate; GO: Gene Ontology; LB: Luria-Bertani; NA: Nutrient agar; NB: Nutrient broth; OD: Optical density; RNA-Seq: RNA sequencing; RT-PCR: Reverse transcription- polymerase chain reaction; sRNA: small non-coding RNA

\section{Acknowledgements}

We are very grateful to Prof. Gongyou Chen (Shanghai Jiaotong University, Shanghai, China) for kindly providing Xac29-1 strain and Prof. Huasong Zou (Fujian Agriculture and Forestry University, Fujian, China) for technical support in hfa mutant construct. We also thank Dr. Jianchi Chen from United States Department of Agriculture, Agricultural Research Service, for critical editing of this manuscript.

\section{Consent to publication}

Not applicable.

\section{Funding}

This study was funded by Chongqing Science and Technology Commission (cstc2016shms-ztzx80003). The funder had no role in the study design, collection, analysis and interpretation of data, or in the writing of the report or decision to submit the article for publication.

\section{Availability of data and materials}

RNA-Seq data are available in NCBI database and the accession numbers of wild type and hfa mutant are PRJNA477585 and PRJNA477663, respectively. The other datasets generated or analysed during this study are included in this published article.

\section{Authors' contributions}

All contributing authors read and approved the manuscript for submission for publication. XW, CZ conceived and designed the experiments. $X L, Y Y, H W$ performed the experiments. $\mathrm{XL}, \mathrm{XW}$ analyzed the data. $\mathrm{XW}, \mathrm{XL}, \mathrm{YY}$ wrote the paper. All authors read and approved the final manuscript.

\section{Ethics approval and consent to participate}

Not applicable.

\section{Competing interests}

The authors declare that they have no competing interests.

\section{Publisher's Note}

Springer Nature remains neutral with regard to jurisdictional claims in published maps and institutional affiliations.

\section{Author details}

National Engineering Research Center for Citrus, Citrus Research Institute, Southwest University/Chinese Academy of Agricultural Sciences, Chongqing 400712, People's Republic of China. ${ }^{2}$ Present address: Agriculture commission of Guangan district, Guangan, Sichuan, China.

Received: 5 March 2018 Accepted: 7 May 2019

Published online: 22 May 2019

\section{References}

1. de F, Fernandez MT, Eoyang $L$, August JT. Factor fraction required for the synthesis of bacteriophage Qbeta-RNA. Nature. 1968;219:588-90.

2. Brennan RG, Link TM. Hfq structure, function and ligand binding. Curr Opin Microbiol. 2007;10(2):125-33.

3. Chao Y, Vogel J. The role of Hfa in bacterial pathogens. Curr Opin Microbiol. 2010;13:24-33.

4. Tsui HC, Leung HC, Winkler ME. Characterization of broadly pleiotropic phenotypes caused by an hfq insertion mutation in Escherichia coli K-12 Mol Microbiol. 1994;13:35-49.

5. Zeng Q, McNally RR, Sundin GW. Global small RNA chaperone Hfq and regulatory small RNAs are important virulence regulators in Erwinia amylovora. J Bacteriol. 2013:195(8):1706-17.

6. Sittka A, Pfeiffer V, Tedin K, Vogel J. The RNA chaperone Hfq is essential for the virulence of Salmonella typhimurium. Mol Microbiol. 2007:63(1):193-217.

7. Hempel RJ, Morton DJ, Seale TW, Whitby PW, Stull TL. The role of the RNA chaperone Hfa in Haemophilus influenzae pathogenesis. BMC Microbiol. 2013;13:134

8. Vogel J, Luisi BF. Hfa and its constellation of RNA. Nat Rev Microbiol. 2011:9:578-89.

9. Valentin-Hansen P, Eriksen M, Udesen C. The bacterial Sm-like protein Hfq: a key player in RNA transactions. Mol Microbiol. 2004:51:1525-33.

10. Waters LS, Storz G. Regulatory RNAs in bacteria. Cell. 2009;136:615-28.

11. Swings JG, Civerolo EL. Xanthomonas. London: Chapman \& Hall; 1993.

12. Leyns F, Cleene MD, Swings JG, Ley JD. The host range of the genus Xanthomonas. Bot Rev. 1984;50:308-56.

13. Liang H, Zhao YT, Zhang JQ, Wang XJ, Fang RX, Jia YT. Identification and functional characterization of small non-coding RNAs in Xanthomonas oryzae pathovar oryzae. BMC Genomics. 2011;12:87.

14. Schmidtke C, Abendroth U, Brock J, Serrania J, Becker A, Bonas U. Small RNA sX13: a multifaceted regulator of virulence in the plant pathogen Xanthomonas. PLoS Pathog. 2013;9:e1003626.

15. Jiang RP, Tang DJ, Chen XL, He YQ, Feng JX, Jiang BL, et al. Identification of four novel small non-coding RNAs from Xanthomonas campestris pathovar. campestris. BMC Genomics. 2010:11:316.

16. Ryan RP, Vorhölter FJ, Potnis N, Jones JB, Van Sluys MA, Bogdanove AJ, Dow JM. Pathogenomics of Xanthomonas: understanding bacterium-plant interactions. Nat Rev Microbiol. 2011;9(5):344-55.

17. Christiansen JK, Larsen $\mathrm{MH}$, Ingmer $\mathrm{H}$, Sogaard-Andersen L, Kallipolitis BH. The RNA-binding protein Hfq of Listeria monocytogenes: role in stress tolerance and virulence. J Bacteriol. 2004;186(11):3355-62

18. Robertson GT, Roop RM. The Brucella abortus host factor I (HF-I) protein contributes to stress resistance during stationary phase and is a major determinant of virulence in mice. Mol Microbiol. 1999:34(4):690-700.

19. Ding Y, Davis BM, Waldor MK. Hfq is essential for Vibrio cholerae virulence and downregulates sigma expression. Mol Microbiol. 2004;53(1):345-54

20. Matilla MA, Krell T. The effect of bacterial chemotaxis on host infection and pathogenicity. FEMS Microbiol Rev. 2018;42(1):40-67.

21. Wilms I, Moeller P, Stock AM, Gurski R, Lai EM, Narberhaus F. Hfa influences multiple transport systems and virulence in the plant pathogen Agrobacterium tumefaciens. J Bacteriol. 2012:194:5209-17.

22. Li J, Wang N. The WxacO gene of Xanthomonas citri ssp. citri encodes a protein with a role in lipopolysaccharide biosynthesis, biofilm formation, stress tolerance and virulence. Mol Plant Pathol. 2011:12(4):381-96.

23. Trobro S, Aqvist J. Role of ribosomal protein L27 in peptidyl transfer. Biochemistry. 2008:47:4898-906.

24. Wower IK, Wower J, Zimmermann RA. Ribosomal protein L27 participates in both 50 subunit assembly and the peptidyl transferase reaction. J Biol Chem. 1998;273:19847-52.

25. Zaher HS, Green R. Hyperaccurate and error-prone ribosomes exploit distinct mechanisms during tRNA selection. Mol Cell. 2010;39:110-20. 
26. Abendroth U, Schmidtke C, Bonas U. Small non-coding RNAs in plantpathogenic Xanthomonas spp. RNA Biol. 2014;11(5):1-7.

27. Kovach ME, Elzer PH, Hill DS, Robertson GT, Farris MA, Roop RM, et al. Four new derivatives of the broad-host-range cloning vector pBBR1MCS, carrying different antibiotic-resistance cassettes. Gene. 1995;166:175-6.

28. Granato LM, Picchi SC, Andrade Mde O, Takita MA, de Souza AA, Wang N, et al. The ATP-dependent RNA helicase HrpB plays an important role in motility and biofilm formation in Xanthomonas citri subsp. citri. BMC Microbiol. 2016;16(1):1-14

29. Yan $Q$, Hu X, Wang $N$. The novel virulence-related gene $n I X A$ in the lipopolysaccharide cluster of Xanthomonas citri ssp. citri is involved in the production of lipopolysaccharide and extracellular polysaccharide, motility, biofilm formation and stress resistance. Mol Plant Pathol. 2012;13:923-34.

30. Fu XZ, Gong $X Q$, Zhang $Y X$, Wang $Y$, Liu JH. Different transcriptional response to Xanthomonas citri subsp. citri between kumquat and sweet Orange with contrasting canker tolerance. PLoS One. 2012;7(7):e41790.

31. Langmead B, Salzberg SL. Fast gapped-read alignment with bowtie 2 . Nat Methods. 2012;9(4):357-9.

32. Li B, Dewey CN. RSEM: accurate transcript quantification from RNA-Seq data with or without a reference genome. BMC Bioinformatics. 2011;12(1):323.

33. Livak KJ, Schmittgen TD. Analysis of relative gene expression data using real-time quantitative PCR and the $2^{-\Delta \Delta C T}$ methods. Methods. 2001;25:402-8.

Ready to submit your research? Choose BMC and benefit from:

- fast, convenient online submission

- thorough peer review by experienced researchers in your field

- rapid publication on acceptance

- support for research data, including large and complex data types

- gold Open Access which fosters wider collaboration and increased citations

- maximum visibility for your research: over $100 \mathrm{M}$ website views per year

At BMC, research is always in progress.

Learn more biomedcentral.com/submissions 